\title{
The Learning Experience of International Students in Canada: Progressive Educational Theory and Passive Learning Styles
}

\author{
Maha Abdulwahed Alzahrani ${ }^{1}$ \\ ${ }^{1}$ Ontario Institute for Studies in Education, University of Toronto, Toronto, Canada \\ Correspondence: Maha Abdulwahed Alzahrani, Ontario Institute for Studies in Education, University of \\ Toronto, Toronto. Canada. E-mail: maha.alzahrani@mail.utoronto.ca
}

Received: May 15, 2018 Accepted: June 10, 2018 Online Published: June 12, 2018

doi: 10.5539/elt.v11n7p76 URL: http://doi.org/10.5539/elt.v11n7p76

\begin{abstract}
This qualitative study examines the experience of Saudi students in the process of learning English while studying in an anglophone country. Through the lens of progressive educational theory and passive learning style, specific factors such as the students' linguistic background and their current experience were explored. This study sought to uncover how these students perceived learning ESL in Saudi Arabia and how their prior learning has affected their current experience overseas. I examined students' insights through the data collected mainly from semi-structured interviews and discourse analysis. In conclusion, the results revealed two major themes including the unprepared learner in Saudi Arabia and the unprepared learner in Canada. Besides, these students were influenced by the passive style they have received before moving to Canada, and they were introduced to a progressive educational system while studying abroad.
\end{abstract}

Keywords: Saudi students, passive style, progressive theory, ESL, learning experience

\section{Introduction}

It is clear that a singular focus on passive learning can often put the student at a disadvantage, as opposed to a constructive method, which also emphasizes developing the student's communicative competence. The role of students' prior language learning history and its impact on their development of linguistic competence and success in an English-speaking environment is becoming more and more crucial. Thus, in this study I seek to provide insights to teachers in Saudi Arabia and the students themselves based on my participants' reflections on their inside- and outside-classroom experience. My self-reflexivity and semi-structured interviews of the participants, together with my review of selected literature on the topic, have led to the formulation of the research described below.

This study will rely on a number of theoretical dichotomies including active vs. passive learning. Influenced by the passive learning I received prior to coming to Canada, which does not adequately prepare students to easily acquire English proficiency, my theoretical framework comes from the concept of investigating the effectiveness of a progressive learning environment typified by more student engagement, learner reflection on topics and projects of interest, and discovery learning (Allen \& Tanner 2003). Progressive (active) education allows students to assume more agency, participation and choice, all of which mitigate stress and lead to more successful outcomes. Further, it is possible that progressive education may empower students to "pass through" gates that are established, such as commonly used English proficiency test scores.

\section{Literature Review}

\subsection{Traditional Education}

The passive learning style is dominant in Saudi culture (Aljohani, 2009; Farah, 2010; Alkubaidi, 2014; Fakieh, 2014 ). While passive learning is not completely absent in the North American educational system, it is apparent that a multiplicity of pedagogical methods are available to the student including more active approaches. Such active approaches encourage students to engage with the curricula through experiential learning, critical thinking, development of analysis and opinion, and independent study where they are allowed to conduct indepth pursuits of topics of personal interest (Bonwell \& Eison, 1991; Sarason \& Banbury, 2004).

Traditional methods in teaching consider the learner's mind a "sponge" which could be filled with information with the expectation that the learner will absorb all that information; this leads to passive learning where learners 
listen to what the teachers say, look at slides of presentations and memorize information presented (StewartWingfield \& Black, 2005; Upadhyaya, 2013). This focus on rote memorization deprives learners of the impetus for creative thinking. Passive education and gatekeeping share the distinction of being undemocratic elements in the educational field and thus have bearing on this study.

\subsection{Educational Reform}

\section{Compulsory learning never sticks in the mind \\ Plato}

The passive learning and teaching style discussed above is contrasted with active learning. As will be discussed throughout this paper, active learning of English in terms of grammar, vocabulary, and dialogue will emerge as an important theme. I will also consider whether students who have been more active in their learning are more likely to be admitted into graduate school. The voice of active learning has been calling out to educators for over one hundred years, an increasingly large thorn in the side of proponents of teaching methods that conform to more traditional, or passive learning pedagogy (also known as back to basics, conventional and didactic education). Active learning is defined as any instructional method that places an important emphasis on engaging students in their education. Active learning also requires students to undertake personally meaningful learning While many individuals have called for progressive education, one of the major proponents that of late $19^{\text {th }}$ and early $20^{\text {th }}$ century philosopher and educator John Dewey. He advocated for an educational environment where a student would be capable of holding and expressing fully formed opinions and eventually be able contribute to civil society in a democratic way, in contrast to the typical American school of the era which he felt was structured to "suppress children's natural curiosity, eagerness to learn, and dynamic activism" (Benson, Harkavy \& Puckett, 2007, p. 28). From 1897 and into the 1920's, he published his then radical thoughts on the learning process which contained recurring liberatory themes, specifically that learning was an interactive process where students could thrive if allowed to interact with the curriculum and take an active role in their own learning, now referred to as "agency". He concurred with traditional theorists that specific content knowledge was necessary; however, he argued that the acquisition of a predetermined set of skills should play a secondary role to the realization of a student's full potential (Dewey, 1938), an idea that can now be encapsulated into terms such as "critical thinking" (Bonwell \& Eison,1991), engaged learning (Bowen, 2005) and reflective practice (Bolton, 2010) A cognitive theorist and psychologist, Jerome Bruner (1961) took the concepts of Dewey, Vygotsky and other constructivism education theorists even further by proposing the concept of "discovery learning" meaning that learners construct their own knowledge for themselves through discovering not receiving from the teacher. He also believed that the best way for learners to acquire the knowledge was through active participation, with "scaffolding" of the teacher when needed (Macleod, 2008). Scaffolding occurs when teachers (or other more advanced learners) support learners to move beyond their zone of proximal development (ZPD) to enable them to accomplish with assistance what they cannot yet do unsupported. When they achieve independence, the scaffolding is removed, and a higher goal is set" (McCloskey, Orr, Stack, \& Kleckova, 2010, p. 1). The actual support may include coaching from the instructor, task modelling, audio and/or visual guides and other resources. The instructor intervenes only insofar as is necessary to guide the learner in in a democratic way, in contrast to the typical American school of the era which he felt was structured to "suppress children's natural curiosity, eagerness to learn, and dynamic activism" (Benson, Harkavy, \& Puckett, 2007, p. 28). From 1897 and into the 1920's, he published his then radical thoughts on the learning process which contained recurring liberatory themes, specifically that learning was an interactive process where students could thrive if allowed to interact with the curriculum and take an active role in their own learning, now referred to as "agency". He concurred with traditional theorists that specific content knowledge was necessary; however, he argued that the acquisition of a predetermined set of skills should play a secondary role to the realization of a student's full potential (Dewey, 1938), an idea that can now be encapsulated into terms such as "critical thinking" (Bonwell \& Eison,1991), engaged learning (Bowen, 2005) and reflective practice (Bolton, 2010) A cognitive theorist and psychologist, Jerome Bruner (1961) took the concepts of Dewey, Vygotsky and other constructivism education theorists even further by proposing the concept of "discovery learning" meaning that learners construct their own knowledge for themselves through discovering not receiving from the teacher. He also believed that the best way for learners to acquire the knowledge was through active participation, with "scaffolding" of the teacher when needed (Macleod, 2008). Scaffolding occurs when teachers (or other more advanced learners) support learners to move beyond their zone of proximal development (ZPD) to enable them to accomplish with assistance what they cannot yet do unsupported. When they achieve independence, the scaffolding is removed, and a higher goal is set" (McCloskey, Orr, Stack, \& Kleckova, 2010, p. 1). The actual support may include coaching from the instructor, task modelling, audio and/or visual guides and other resources. The instructor intervenes only insofar 
as is necessary to guide the learner in the appropriate direction (Cooperstein \& Kocevar-Weidinger, 2004) instead of providing the solution to the question, case or problem. This is a key feature of discovery learning that differentiates it from passive learning models in that the former is geared towards producing active learners where students are obligated to participate in problem-solving projects rather than mere knowledge transfer (Castranova, 2002). In turn, this process of discovering, processing and applying information, has been found to greatly enhance learners' critical thinking abilities (Allen \& Tanner 2003). In the tradition of Dewey, Paulo Freire is considered a major contributor to the progressive education movement whose ideas grew out of his adult literacy work throughout Brazil prior to that country's 1964 military coup. Freire (1970) proposed an alternative to the "banking concept" of education. Freire critiqued banking by defining it as an act where the teacher (subject) "deposits" information into the student (object) who meekly receives, memorizes and repeats the program content delivered. In other words, the teacher is the depositor while the students function as the depository. Reality is presented as if it were "motionless, static, compartmentalized, and predictable ... [o]r expounds on a topic completely alien to the existential experience of the students" (Freire, 1970, p. 71). Freire characterized a banking environment as one where the teacher knows all, thinks, speaks, and chooses the program content; conversely the student knows nothing; is thought about, listens, and most important, has no say in the program content, and instead must adapt to it. In his role as Coordinator of the Adult Education Project of the Movement of Popular Culture in Recife, Brazil, Freire, in collaboration with his colleagues, established a literacy program consisting of culture circles in in the villages of Recife to make inroads into educating the approximately sixteen million illiterates aged fourteen and older. The program was deliberately designed to counteract what Freire saw as the passive nature of the traditional school. Of this initiative, he wrote "Instead of a teacher, we had a coordinator; instead of lectures, dialogue; instead of pupils, group participants; instead of alienating syllabi, compact programs that were "broken down" and "codified" into learning units (Freire, 1973, p. 42). Course content such as nationalism, vote for illiterates, and the political evolution of Brazil was offered on request of the participants thereby mirroring their lives and interests. Knowledge was schematized, presented with visual aids and discussed through an exchange of ideas among participants and with the coordinator whose role was to engage them in critical dialogue aimed at clarifying their social reality, realizing possibility for change and spurring action (Freire, 1973).

Freire's program sought to go beyond a mere "mechanistic" literacy to one where adults would read and write "in relation to the awakening of their consciousness" (Freire, 1973, p. 43) showing people they had the power to think for themselves, act based on their thinking and thus determine their future, in contrast to the silence and conditioned apathy under which they had lived before (Freire, 1970).

Within these culture circles could be found elements of five major agreed upon principles of constructivist learning that researchers have induced in the decades since Freire began his work:

1). Engaging in activities simulating those found in real life, presented in a way that allows the learner to discover their own truths.

2). Manipulating and extending learning discoveries while incorporating this knowledge into pre-existing belief systems.

3). Making sense of new information within the context of prior knowledge through comparing, contrasting, questioning, and challenging this information.

4). Focusing more on the development of the skills than on the conveyance of facts.

5). Interacting socially with others, giving the learner the opportunity to compare and share ideas collaboratively and resolve any conflicts that may arise (Bonwell and Eison, 1991; Good and Brophy, 1994; Cooperstein \& Kocevar-Weidinger, 2004).

Key to the active learning process are the reflectiveness of the process where learners critically reflect on what they learn (Barnes, 1989) and the relevancy to the learner's needs and concerns. The tasks provided to learners should help the students to be able to make the comparison with the complexities in the real life. Negotiation of the goals and approaches of learning is essential between both parties- teacher and learner. That is, active learning, in contrast to the passive, is a negotiated process.

Up to the late 1980s, passive education was the dominant mode of instruction in the North American educational system (Bonwell \& Eison, 1991). Throughout the 1980s, several leaders in the field of higher education began to advocate for an increased use of active learning within college and university classrooms. These calls for active learning were supported by a collection of national reports that noted the importance of this pedagogical approach (Bonwell \& Eison, 1991). In the decades since, the active learning movement has continued to garner 
theoretical and empirical support. Ongoing research has consistently supported the finding that passive, superficial learning engendered at the undergraduate level could lead to students completing their degrees while lacking the important critical analysis and thinking skills required for professional success (National Research Council, 2007). The problem assumes a political dimension since the US seeks intellectual dominance in the global market and needs an extensive cadre of critical, problem-solving and innovative professionals in all major disciplines, especially in mathematics and the sciences, to accomplish this.

Several empirical studies have shown the positive effect of active learning on students' overall learning (attitude and performance), for example, their performance in writing essays, scientific inquiry, class participation and cognitive outcomes (Seipel \& Tunnell, 1995; Benek-Rivera \& Matthews, 2004; Strow \& Strow, 2006; Armbruster, Patel, Johnson, \& Weiss, 2009; Khalid \& Azeem, 2012).

Bean (2011) advocates for the active learning method in classroom instruction, believing that this kind of learning should change the role of learner from passive listener to active participant as well as help the learner gain a deep understanding of the lessons through asking questions and gathering and analyzing the materials, lending credence to the earlier work of Bonwell and Eison (1991) who also emphasized the learner's role in reading, writing, discussing and being engaged in solving problems; in short, to be actively involved. Bonwell and Eison (1991) contributed significantly to the development of active learning, suggesting several methods to promote active learning in the classrooms. Among them are the following: learners can work together, negotiate the materials while role-playing, debate the pros and cons of an issue, and compose short written exercises. Moreover, students have to engage in tasks that require them to analyze and evaluate. In this context, activities that promote active learning are defined as instructional activities that involve students in not only producing things (projects, assignments etc.) but also in analyzing and thinking about what they are performing. Learning is further constructed through social interaction with peers and with the teacher whose communication encourages an inductive route to solution finding (Cooperstein \& Kocevar-Weidinger, 2004).

Active learning appears to be more consistent with human functioning. Children love to explore the world from a very young age including touching and pulling apart objects they encounter, all the way to engaging in activities adults would consider dangerous. This drive opposes notions of passivity. In other words, children's early years are replete with opportunities to learn informally and actively. It is the act of being placed into the formal school system that begins the socialization process where children are forced into the role of passive listener student (Upadhyaya, 2013).

\section{Methods}

\subsection{Participants}

I interviewed Fourteen participants, one man and 13 women. Both genders were welcomed to participate in the study. I was seeking a more equitable distribution of male and female participants, but only two men showed interest and only one followed through with an interview. Participants were solely composed of individuals educated in Saudi Arabia before moving to Canada. It was essential to ensure that these individuals underwent the largest portion of their education in Saudi Arabia, including their time spent receiving English language instruction. The other requirement from the participants was their interest and willingness to be a part of my study. The ages of the participants were between 22 and 30 since one of the conditions for the applicant to be eligible for a scholarship is that he or she must not be over 27 years old at the time of application.

Considering the time participants dedicated to learning the language and the period of graduate studies, I thought that limiting the age to 30 years old seemed like an adequate barometer to ensure that the length of their English exposure was similar.

\subsection{Research Design}

\section{Narrative approach}

In this study, I employed a qualitative study to investigate the particular difficulties encountered by Saudi students who have moved to Canada. Specifically, I utilized a narrative approach. Creswell (2013) describes the methodology as a mechanism for information sharing, particularly using tools such as interviews. For the purpose of this study, this approach was ideal as it involves in-depth investigation while allowing for data collection through a variety of avenues.

\subsection{Analysis}

The analysis of qualitative research presents a number of opportunities which can help the researcher to gather thick description in response to the questions required to derive full benefit from the process (Creswell, 2013). 
Primarily, interview questions were considered in terms of major themes that may arise upon analysis. These themes were derived from both an inductive and deductive approach. Inductive reasoning moves from specific, often anecdotal observations, to broader generalizations and theories in what is known as a "bottom up" approach. It involves a degree of uncertainty in that new information that the researcher does not anticipate may arise from participant answers.

\section{Result}

This section presents an overview of the two essential themes that emerged during data analysis. Each theme explores the relationship the student is having with their educational landscape as a learner at a particular time between applying for the scholarship in Saudi Arabia and completing their studies in Canada whether through graduating or concluding their studies under less ideal conditions.

\subsection{The Unprepared Learner in Saudi Arabia}

\section{Prior learning}

The initial excitement of being in Canada is soon tempered by the challenging reality of ESL study and the high stakes testing over which students must prevail. A great amount of time was spent during the interviews discussing the endless cycle of IELTS test attempts and other efforts students made to demonstrate English proficiency to Canadian standard.

Most of the participants felt their prior learning in Saudi Arabia had not prepared them adequately for their studies in Canada and furthermore, that their ESL and IELTS preparation studies in Canada did not prepare them adequately to compile their graduate school dossier. This led to the emergence of the notion of the unprepared learner. The participants shared their learning histories with me at great length and depth, then indicated to what extent this preparation furthered or hindered their scholarship experience: first, their ability to navigate the ESL studies and IELTS requirements for graduate school, and second, their ability to prepare the more subjective aspects of their graduate school application package, namely the CV and the letter of intent. These revelations created two subthemes, a) the unprepared learner in Saudi Arabia and b) the unprepared ESL learner in Canada.

Regarding their prior English learning in Saudi Arabia, 11 of the participants began learning English in public school at the intermediate level when they were 13 years old. Intermediate level is equivalent to grade seven in the Canadian education system. Leena, Nada and Rawa reported that they had studied English in private school from grades one to three, and in grade four were transferred to public schools where no English instruction was offered until grade seven. Those participants did not perceive having an advantage over those who had studied in public schools from grade 1 in terms of reading comprehension and speaking.

Maha: Did you study in public or private school?

Nada: I studied from grade one to three in private school then I went to public [school].

Maha: Did you benefit from the three years?

Nada: To be honest, no. I don't remember that I was good in English.

No participant learned English entirely in private schools. Participants' university backgrounds differed; some were science majors while others were business majors. Most of them had received instruction in Arabic. Kadi, who studied nutrition, said that even "when some courses were supposed to be given in English, the instruction was in Arabic". However, Rama, who studied nursing, did take her courses in English for four years along with Ahmad who completed his degree in dentistry schools in English instruction only. Ahmad shared his story saying:

I studied Dentistry on the undergraduate level for 6 years, during which English was the only language of professional education, exams, clinical, and extracurricular scientific activities. That boosted my proficiency in English.

What surprised me the most about the participants' responses was the grades they had received in Saudi Arabia before they moved to Canada. Most of them reported that they had good grades in English, for example B and $\mathrm{B}+$. Some hesitated before answering, perhaps to remember their grades and compare them to those earned in Canada.

Maha: How were your grades in Saudi Arabia?

Noura: Umm, I am not sure, I think they were good.

I believe that the participants did not struggle with grades since they learned the curriculum deposited by the 
teacher by heart and were able to reproduce memorized work during tests. Rather, their ability to speak and compose spontaneous writing became obstacles to their progress once they moved to Canada.

Nada, who said she had chatted through English classes in Saudi Arabia because of the boredom of listening to the teacher's soft voice drone on and on in lecture style, questioned whether her studies there had impacted her subsequent English studies in Canada. Once she arrived in Canada, she had to start at the beginner level after enrolling at a popular Toronto language school, a clear indication of a significant deficiency in the skills required to function at university. Similarly Basmah expressed uncertainty about her former learning- "all memorization and regurgitation from grade 7 through her undergraduate years". She had to enroll at beginner level English in Canada despite her prior studies.

All Saudi-schooled students agreed that English was categorized as a low-priority subject compared to other aspects of the curriculum such as mathematics and science. All the participants were critical of their respective schools' English instruction. Views on English instruction varied among the participants, but most of them had negative experiences with learning the language for several reasons including teaching methods, curriculum, instructors' attitude and personal motivation. A common trend among the participants was the use of memorization when they were learning English in their home countries. Nine of the 14 participants: Sarah, Muna, Leena, Deema, Noura, Shahad, Rama and Nada reported that they had to memorize essays and regurgitate the exact same material on tests. In so doing, they always received high grades.

Rama: "Sometimes I did not know what I [was] writing; it was just like copy and paste."

Nada was especially frustrated by the memories this question evinced, noting that "I remember we had memorize writing for tests. How is that possible? [English] was just a course, not a skill."

Muna also commented on her ESL in Saudi Arabia: Muna: The methods were ineffective and badly planned. Maha: Could give me an example?

Muna: They were using traditional methods. I hated English during all my previous life. It was really boring.

Maha: What do you mean by traditional?

Muna: They write on the board, used CD players and gave us homework related to the lesson somehow.

When I asked Noura about her prior English learning in Saudi Arabia, she said, Noura: I don't consider that as learning.

Maha: Why?

Noura: You know how they teach English there. I just memorize.

Maha: You compared it to the Canadian experience, I think.

Noura: Yes, sure. I started here from the beginning, I knew that I did not learn that much in Saudi.

She did not value what she learned there as much as what she learned in Canada. Furthermore, Noura complained that the curriculum never helped her to speak English because, perhaps, the teachers regularly spoke Arabic in the classroom. She said, I came here to Canada, and all people around me speak English; I managed to understand. So if in Saudi [Arabia] teachers [speak] English in the English courses, we will get used to it, and we will understand [even better].

Nada talked about the effect of her traditional learning in Saudi Arabia,

"It does not depend on the curriculum. It depends on how we are motivated. At that time I was not motivated to [learn] English."

Nada did not feel she had ineffective teachers, describing them as "kind" professionals who provided solid instruction. But, she said "The classes were boring", leading the students to chat with each other instead of paying attention. For her, studying English was only a hurdle she needed to jump over to be promoted to the subsequent grade. She memorized enough to avoid failing because students who failed would have to retake the test before being promoted; yet, it was not a subject to be taken seriously like mathematics or science. At that time she did not realize how crucial the language would be in meeting her career goals. Rama, Deema and Leena agreed that teachers in Saudi Arabia did not focus on creative writing skills; they focused on grammar and vocabulary. They did not know how to deliver the information. Leena lamented the irrelevancy of course content, recounting that "We learned things that I am not going to use in my daily life." Kadi reflected on her prior learning experience in Saudi Arabia:

Kadi: I remembered in Saudi Arabia, teachers focused on just delivering the content from the textbook instead of 
making effort to make the lessons interesting for us.

Maha: Can you give me an example?

Kadi: Yes, for example, a grammar rule that needs to be practiced not only writing the rule on the board, explain it out loud and that's it.

Maha: That's hard, I know.

She believes that her teachers were only focusing on delivering the information without checking if the students understood the material. In other words, teachers were not interested in how the students were doing. I assumed that this lack of both interest and scaffolding method impacted the learners.

Basmah commented on the same point that Saudi teachers focused on "grammar without asking us to give examples". She meant that teachers did not give them the time to discuss the lessons and practice reflection on what they learned. Afnan and Leena concluded on their prior learning by noting that she thinks the teaching methods have changed since she was a student in Saudi Arabia. They were optimistic about the current statue of ESL in Saudi Arabia.

\section{Discussion}

\subsection{The Unprepared Learner}

As explained in the results, most participants complained about ESL instruction in Saudi Arabia and felt that pedagogy put them at a disadvantage when they came to Canada. In Saudi Arabia, English is usually taught by employing a passive pedagogical style and as a result through lectures and memorization for tests with a glaring lack of speaking practice. The theme "unprepared learner" emerged from the fact that the participants did not benefit from the ESL in Saudi in terms of absorbing the foundational content of English (creating the subtheme of unprepared learner in Saudi Arabia); therefore, when they arrived in Canada, none qualified for direct entry into graduate school and many had to recommence their ESL studies as beginners after at least 6 years of formal instruction in high school and a further 4 years of instruction at the undergraduate level (hence, unprepared in Canada also).

\subsection{Unprepared Learner in Saudi Arabia}

When a young student must endure learning to adult standards, subject matter and methods imposed from above and from outside, the material is inaccessible (Dewey, 1938). Dewey notes that "The gap is so great that the required subject matter, the methods of learning and of behaving are foreign to the existing capacities of the young. Consequently, they must be imposed; even the good teachers will use devices of art to cover up the imposition so as to relieve it of obviously brutal features" (p. 6). This could account for the inability of students to perform in a language that had been with them from childhood.

Those who blamed their teachers, the content of curriculum and the methods employed back home used words as "boring", "not motivated", "uninteresting", "ineffective" to describe ESL in Saudi Arabia. Students did not choose materials or introduce topics they were interested in for discussion in class. This connects with the concept of "banking education" (Freire, 1970) where each Saudi student was indeed a "depository" of what the teacher said and presented.

The banking method of knowledge transfer had not allowed Saudi students to engage deeply and meaningfully with English in the simulated environment that is the classroom. Thus they could not go on to apply the knowledge in the real world, particularly in a community populated by native speakers of English. Had the Saudi classroom provided students with the opportunity to practice English in class, and incorporate class resources to create written and spoken material relevant to their interests, and other experiential supports as suggested by Barnes (1989), Prince (2004) and others, they would have more than likely developed their ESL skills to a greater degree.

Dewey's observation that even good teachers used devices in an attempt to obscure the imposition, dovetails with Nada's description of her English teacher "as kind". However, the pleasant nature of an instructor is not sufficient compensation for a stifling curriculum as demonstrated by the students' lack of attention in class in favor of chatting with each other. Plus, I do not think those teachers themselves were then, or are now, critically aware of their role in the system. They just follow instructions from the Ministry of Education, which in turn is part of a society that follows strict religious rules.

\subsection{Unprepared Learner in Canada}

Some of the participants felt unprepared to navigate the education system in Canada, a perception that was 
reflected by the many attempts in taking the IELTS, multiple graduate applications submitted and studying ESL to the point of burn out. In line with prior research (Zuriff, 1977; Fairtest, 2007; Dooey, 2008) participants of this study suffered from anxiety and loss of interest which led them to burning out; for Noura and Nada, they had to step away from their courses entirely.

The test not only resulted in stress for the students, but it also interfered with the improvement of their language skills, an interference that was evident in their low scores. This connects to the detrimental effects of high stakes testing on learners observed by Taylor (2005) and Fairtest (2007). The many test attempts along with the pressure of the scholarship timeline negatively affected participants in their ESL journey.

This finding also supports the assertion that passive learning creates undue stress for the learner because humans are not simple receptacles who easily process and transfer information passively received. The integration of new knowledge requires effort to make sense of the input and take ownership of it (Cooperstein \& KocevarWeidinger, 2004). The students who burnt out were operating within and relying upon a formal, passive learning system and repeatedly using the same unprofitable strategies in an attempt to overcome IELTS-gate. Those who interrupted this pattern, and embarked upon a critical reflection of what they were doing (Friere, 1970; Sarason \& Banbury, 2004) managed to step out of the ESL class/IELTS test cycle and figure out alternative, more profitable strategies of getting into graduate school. These participants gave rise to the theme "engaged learner".

\section{Limitations and Suggestions}

Participant selection posed a significant challenge to this study. The current research focused explicitly on those students who have spent the bulk of their education in Saudi Arabia, learning English primarily through public and private educational settings. While finding participants that matched such criteria proved to be challenging, the qualitative narrative approach of this study allowed me to gather a great deal of information from the participants that I found. Considering the narrative approach used to explore this study, the generalization of results can be another area of concern. Furthermore, the collected data in this study focused on a narrow group of population. Thus, I assumed that the results obtained after conducting my research are mainly applicable to other fellow Saudi students. As a result, to draw conclusions and reliable comparisons to speakers of other languages such as Mandarin or Spanish, further investigations should be conducted.

My study explored Saudi students' perceptions about their English learning experience in Saudi Arabia and Canada. More research could look at current teaching methods and practices in the Saudi context. Besides, more research could be conducted on how to prepare students who are planning to study abroad in the future to make their journey more accessible and beneficial.

\section{Conclusion}

It is also clear that Saudi student's English language skills could be remediated at earlier stages as recommended by Lopez and Tashakkori (2004), who studied children exposed to both English and Spanish in the US. By rectifying early problems, teachers in Saudi Arabia could guide students to be able to speak and write at levels close, or even equal, to that of proficient English speakers. This in turn would increase the likelihood of Saudi Arabian students successfully integrating into the Canadian tertiary education system.

\section{References}

Al-Johani, H. M. (2009). Finding a way torward the impact of teachers' strategies, beliefs and knowledge on teaching English as a foreign language in Saudi Arabia. (Doctoral dissertation). University of Strathclyde: Glasgow, Scotland, UK.

Alkubaidi, M., A. (2014). The relationship between Saudi English major university students' writing performance and their learning style and strategy use. English Language Teaching, 7(4), 83-95. https://doi.org/10.5539/elt.v7n4p83

Allen, D., \& Tanner, K. (2005). Infusing Active Learning into the Large Enrollment Biology Class: Seven strategies, from the simple to complex. Winter 2005. University of Delaware, Newark, Delaware, San Francisco State University. https://doi.org/10.1187/cbe.05-08-0113

Armbruster, P., Patel, M., Johnson, E., \& Weiss, M. (2009). Active learning and student centred pedagogy improve student attitudes and performance in introductory biology.

Benek-Rivera, J., \& Mathews, V. E. (2004). Active learning with jeopardy: Students ask the questions. Journal of Management Education, 28, 104-118. https://doi.org/10.1177/1052562903252637

Benson, L., Harkavy, I., \& Puckett, J. (2007). Dewey's Dream: Universities and democracies in an age of education reform. Philadelphia: Temple University Press. 
Bonwell, C., \& Eison, J. (1991). Active learning: Creating excitement in the classroom. ASHE-ERIC Higher Education Report No. 1. Washington, DC: The George Washington University, School of Education and Higher Education.

Bowen, S. (2005). Engaged learning: are we all on the same page? Association of American Colleges and Universities, 7(2), 4-7.

Brown, R., M. (2004). Self-composed rhetoric in psychology personal statements. Written Communication, 21(3), 242-260. https://doi.org/10.1177/0741088304264338

Bruner, J. S. (1961). The act of discovery. Harvard Educational Review, 31, 21-32.

Castronova, J. (2002). Discovery Learning for the 21st Century: What is it and How Does it Compare to Traditional Learning in Effectiveness in the 21st Century? Action Research Exchange, 1(1).

Cooperstein, S. E., \& Kocevar-Weidinger, E. (2004). Beyond active learning: a constructive approach to learning. Emerald group publishing limited, 32(2), 141-148. https://doi.org/10.1108/00907320410537658

Creswell, J. W. (2013). Qualitative inquiry and research design: Choosing among five approaches (3rd ed.). Los Angeles: SAGE Publications.

Dewey, J. (1938). Experience and education. Retreived from http://ruby.fgcu.edu/courses/ndemers/colloquium/experienceducationdewey.pdf

Dooey, P. (2008). Language testing and technology: Problems of transition to a new era. ReCall, 20(1), 21-34. https://doi.org/10.1017/S0958344008000311

Fairtest. (2007). The Dangerous Consequences of High-Stakes Standardized Testing. Retrieved from http://www.fairtest.org/dangerous-consequences-highstakes-standardized-tes

Fareh, S. (2010). Challenges of teaching English in the Arab world: Why can't EFL programs deliver as expected? Procedia-Social and Behavioral Sciences, 2(2), 3600-3604. https://doi.org/10.1016/j.sbspro.2010.03.559

Freire, P. (1970). Pedagogy of the oppressed. (30 ${ }^{\text {th }}$ Anniversary edition reissued in 2005). New York: Continuum.

Freire, P. (1973). Education for Critical Consciousness. New York: Seabury Press.

Furka, I. (2008). The curriculum vitae and the motivational letter: a rhetorical and cultural analysis. WoPaLP, (7), 18-73

Good, T., L., \& Brophy, J., E. (1994). Looking in Classrooms, HarperCollins College Publishers, New York, NY.

Keith-Spiegel, P., \& Wiederman, M. W. (2000). The complete guide to graduate school admission: psychology, counseling, and related professions.

Khalid, A., \& Azeem, M. (2012). Constructivist Vs Traditional: Effective Instructional Approach in Teacher Education. International Journal of Humanities and Social Science, 2(5), 170-177.

Lopez, M. G., \& Tashakkori, A. (2004). Effects of a two-way bilingual program on the literacy development of students in kindergarten and first grade. Bilingual Research Journal, 28, 19-34.

McLeod, S. A. (2008). Bruner. Retrieved from www.simplypsychology.org/bruner.html

McCloskey, M. L., Orr, J., Stack, L., \& Kleckova, G. (2010). Scaffolding Academic Language for English Learners: What, Why, How? 1-6. Retrieved from http://www.mlmcc.com/docs/2010-03-TESOLScaffolding-HO.pdf

Mukattash, L. (1981). Problems in error analysis. Washington, DC: Center for Applied Linguistics.

National Research Council. (2007). Taking Science to School: Learning and Teaching Science in Grades k-8. Washington D.C. Committee on Science Learning.

Prince, M. (2004). Does active learning work: A review of the research. Journal of Engineering Education, 93(3), 223-232

Sarason, Y., \& Banbury, C. (2004). Active learning facilitated by using a game-show format or who doesn't want to be a millionaire? Journal of Management Education, 28, 509-519. 
Seipel, C., \& Tunnell, L. (1995). Using a comment sheet to grade accounting writing assignments. Accounting Educators' Journal, 7, 159-165.

Stewart-Wingfield, S., \& Black, G. S. (2005). Active versus passive course designs: The impact on student outcomes. Journal of Education for Business, 81, 119-125.

Strow, B., K., \& Strow, C. W. (2006). A rent-seeking experiment for the classroom. Journal of Economic Education, 37, 323-330.

Taylor, L. (2005). Washback and Impact. ELT Journal, 59(2), 154-155.

Thompson-Panos, K., \& Thomas-Ruzic, M. (1983). The least you should know about Arabic: Implications for the ESL writing instructor. TESOL Quarterly, 17, 609-623.

Upadhyaya, A. (2013). Active vs. Passive Learning. Retrieved from http://blog.edubrite.com/2013/01/24/activevs-passive-learning/

Zuriff, G. E. (1997). Accommodations for test anxiety under ADA? J. Am. Acad. Psychiatry Law, 25(2), 197206.

\section{Copyrights}

Copyright for this article is retained by the author(s), with first publication rights granted to the journal.

This is an open-access article distributed under the terms and conditions of the Creative Commons Attribution license (http://creativecommons.org/licenses/by/4.0/). 